\title{
County-Specific Chill Hours Accumulation in South Carolina
}

\author{
José O. Payero*, Udayakumar Sekaran \\ Clemson University, Edisto Research and Education Center, Blackville, SC, USA \\ Email: ^jpayero@clemson.edu
}

How to cite this paper: Payero, J.O. and Sekaran, U. (2021) County-Specific Chill Hours Accumulation in South Carolina. At mospheric and Climate Sciences, 11, 508519.

https://doi.org/10.4236/acs.2021.113030

Received: April 28, 2021

Accepted: June 15, 2021

Published: June 18, 2021

Copyright (อ 2021 by author(s) and Scientific Research Publishing Inc. This work is licensed under the Creative Commons Attribution International License (CC BY 4.0).

http://creativecommons.org/licenses/by/4.0/ (c) (i) Open Access

\begin{abstract}
Winter chilling is critical for most temperate fruits and perennial plants during the winter season. Most fruit and nut trees require a prolonged period of chilling to break their dormant stage and bloom when spring arrives. This research's primary objective was to calculate the chill hour's accumulation in each county in South Carolina based on the historical hourly air temperature data for the last ten years (2010-2020). The chilling hours model used to calculate the daily chill hours was based on the number of hours when the air temperature was between $32^{\circ} \mathrm{F}$ to $45^{\circ} \mathrm{F}\left(0\right.$ to $\left.7.2^{\circ} \mathrm{C}\right)$. The total chill hours for each county were then determined by accumulating the daily chill hours from October to June. Our results showed that among the different counties in South Carolina, on average Laurens County had the most prolonged chill hours (1419 hrs). The chill hours were higher between November to March, and counties near the coastal regions had fewer chill hours than the counties in the inland areas. For example, Beaufort, Charleston, Berkeley, Horry, and Dorchester counties that are located near the coastal region had fewer chill hours. In contrast, counties located in the inland areas like Laurens, Chester, Lancaster, and York recorded the most prolonged chill hours. Our results suggest that selecting high chilling requirement crops for the inland areas and low chilling requirement crops for coastal areas would be appropriate. Farmers in South Carolina can use this information to plan their crop selection and management.
\end{abstract}

\section{Keywords}

Chill Hours, Air Temperature, South Carolina, Coastal Area, Dormancy

\section{Introduction}

Winter chilling is critical for most temperate fruits and perennial plants [1]. To 
avoid frost injury during winter, many plant species become dormant in the fall season and resume their growth after fulfilling their chilling requirement (i.e., exposure to a particular duration of cold temperature). Most fruit and nut trees require a prolonged period of chilling to break their dormant stage and bloom when spring arrives [2]. In other words, these plants need a certain number of hours of temperatures between $32^{\circ} \mathrm{F}$ and $45^{\circ} \mathrm{F}\left(0\right.$ and $\left.7.2^{\circ} \mathrm{C}\right)$. During the fall, plants will produce a hormone known as abscisic acid (stress hormone) that promotes shedding of leaves and enter a dormant state [3]. The abscisic acid concentration will diminish after the prolonged period of cold (i.e., below $45^{\circ} \mathrm{F}$ ). After experiencing its required amount of chilling time, plants will be ready for flowering and resume normal growth in spring [4]. However, if chilling time was insufficient either quantitatively or qualitatively, it can lead to delayed foliation, reduced fruit set and reduced fruit quality [5]. Erez and Fishman [6] observed significant differences in chilling requirements between and within species. The chill-hour requirement of some fruit trees is higher and other trees have low chill-hour requirements. For example, fruit trees like apple, blackberry, citrus, peach, and pomegranate required $200-1000,200-600,0-100,200-800$, and 100 - 200 chill hours, respectively [7].

Many mathematical models are available to estimate chill hours from meteorological data [8] [9]. Generally, there are three common models used to calculate chill hours and define the chilling unit: 1) chilling hours model (temperature between 0 and $7.2^{\circ} \mathrm{C}$ ), 2) the Utah model, and 3) the Dynamic model. In the 1950's, Weinberger [10] estimated the chill hours based on observations of the number of chilling hours that were required for a peach cultivar to break its dormancy at Fort Valley, GA, USA. The threshold temperature used in this model was $7.2^{\circ} \mathrm{C}\left(45^{\circ} \mathrm{F}\right)$ and many researchers are still using this model [11]. According to Fishman et al. [12], adopting the Dynamic model in warm winter areas gives a good estimation of the chilling accumulation. Dynamic model calculates chill in units known as "chill portions", based on hourly temperature. Similar to the dynamic model, the positive Utah model is also used for warm climate areas [13]. There are many other different models available to calculate chill hours, like the Mean Temperature model [14], the Low Chill model [15], the hours below $11^{\circ} \mathrm{C}$ model [16], and the Taiwan model [17]. Various studies observed the chilling requirement for many crops and the largest effects have occurred above freezing temperature [18] [19] [20]. Erez and Fishman [6] used various temperature conditions from different warm locations to demonstrate the dynamic model's performance. They found that the main cause of poor bud growth in small peach trees was an increase in day temperature rather than low night temperature. Sunley et al. [8] used various methods to calculate winter chill including the Utah model to determine the impact of winter chill on bud break and fruit quality.

In the past, models used either manually recorded hourly temperature observations or thermograph charts to determine chill hours. Richardson et al. [21] 
used a straight line with $12 \mathrm{hrs}$ between maximum and minimum temperature to calculate chill hours. Since hourly temperature data are often lacking, Linvill [22] used a sine-logarithmic approximation of the daily heating wave to determine chilling hours and chill units using daily maximum and minimum temperatures and day-length. Summing up seasonal hours between 0 to $7.2^{\circ} \mathrm{C}$ is the easiest and most widely used approach to estimate winter chill hours in horticultural production [10] [23].

South Carolina grows a wide variety of field crops, vegetable crops, and fruit and nut trees throughout the year because of its relatively mild climate. However, the growing season varies from year to year due to different seasonal weather patterns. Farming variables derived from weather data, such as local chill hours accumulation become valuable to farmers if presented in a simplified form. Currently, there is a lack of local information regarding the accumulation of chill hours in South Carolina. Therefore, this research's objective was to calculate the chill hour's accumulation in each county in South Carolina based on the historical hourly air temperature data for the last ten years (2010-2020) between October to June. Farmers in different South Carolina counties can use this local information to plan their crop selection and management.

\section{Methods}

This study was conducted at the Clemson University Edisto Research and Education Center, which is located near Blackville, South Carolina. The climate in this region is humid and subtropical (Köppen climate classification Cfa) with long and hot summers and short mild winters. In summer, the day temperatures are often $>32^{\circ} \mathrm{C}$ and the nights are mild to warm in the $19^{\circ} \mathrm{C}$ to $24^{\circ} \mathrm{C}$ range. The coastal regions of the state are warmer than the interior. During winters, the day temperatures are between $14^{\circ} \mathrm{C}$ to $17^{\circ} \mathrm{C}$ and the night temperatures are between $3^{\circ} \mathrm{C}$ to $6^{\circ} \mathrm{C}[24]$.

For this study, hourly air temperature data by county in South Carolina were obtained covering the period from October 1 to June 1 for the years 2010 to 2020. South Carolina has a large number of weather stations covering the entire state, which are part of different weather station networks (i.e., ECONET, COOP, NOAA) maintained by several organizations. This information was available via the NC Climate Retrieval and Observation Network of the Southeast Database (NC CRONOS/ECONet Database). The NC CRONOS/ECONet Database (https://climate.ncsu.edu/cronos/) was developed by the State Climate Office of North Carolina to provide archived weather information from almost 40,000 weather sites, including sites in South Carolina.

For this study, hourly air temperature data for most of the 46 counties in South Carolina (a few counties had no data) were obtained using the NC CRONOS/ECONet Database's API. An R script [25] was developed to make http requests to the database and download, analyze, and plot the data from each county's weather station. The daily chill hours were calculated using the R script 
by counting the number of hours when the air temperature was within $32^{\circ} \mathrm{F}$ and $45^{\circ} \mathrm{F}\left(0\right.$ and $\left.7.2^{\circ} \mathrm{C}\right)$. The total chill hours for each county were then determined by accumulating the daily chill hours starting on October $1^{\text {st }}$.

\section{Results and Discussion}

The ten-year average of daily chill hours data between October to June for various counties are given in Figures 1-5. On average, more prolonged daily chill hours were observed between the months of November to March in all the counties. The mean daily chill hours in different counties ranged from 2.89 to 5.79 (Figures 1-5). The lowest mean daily hours were observed in Beaufort

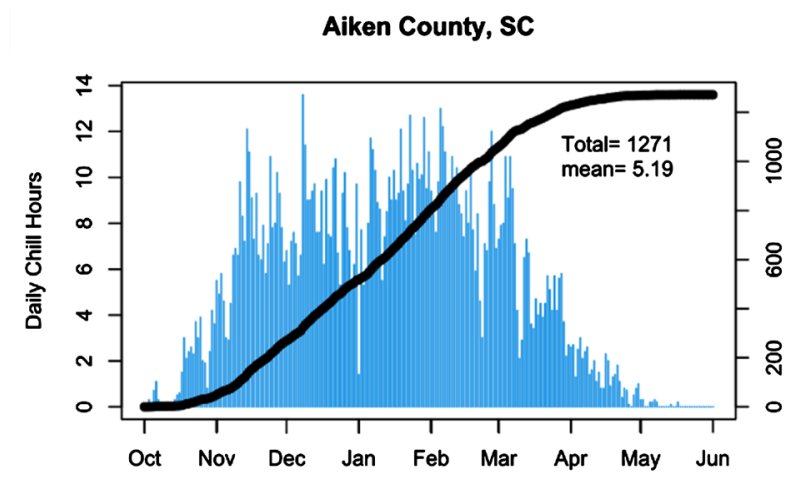

Barnwell County, SC

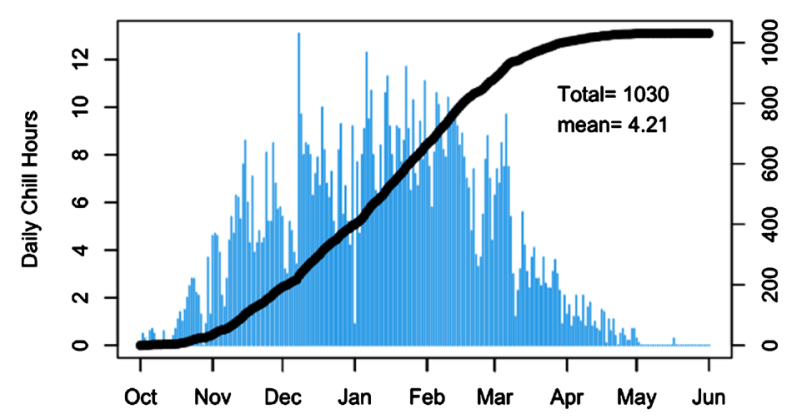

Berkeley County, SC

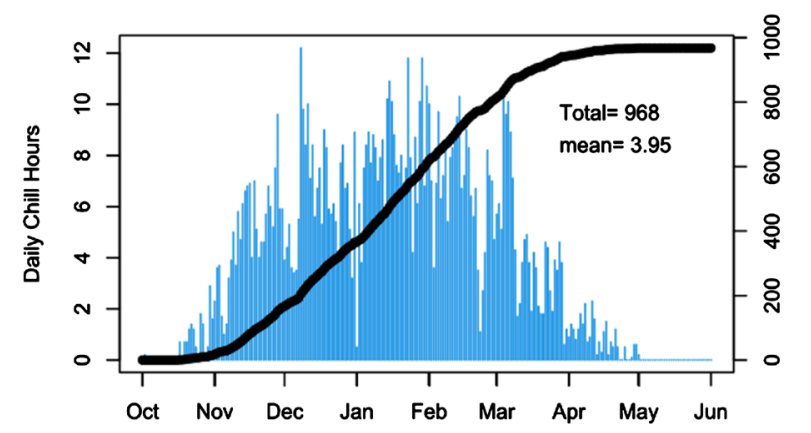

Anderson County, SC

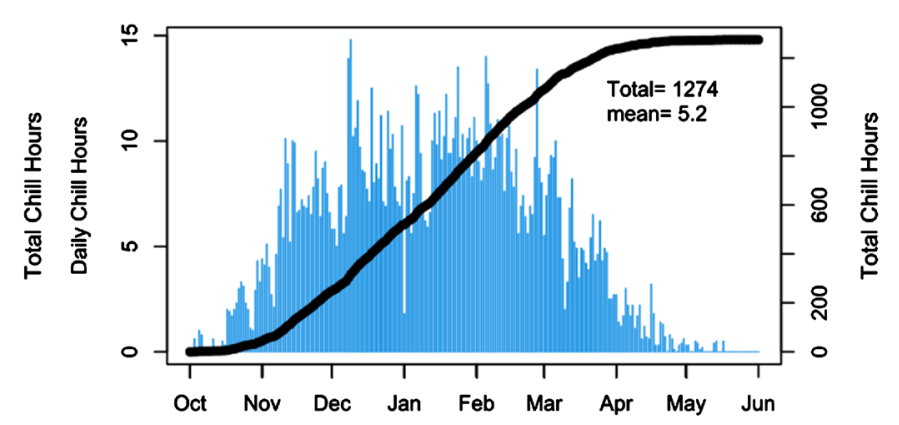

Beaufort County, SC

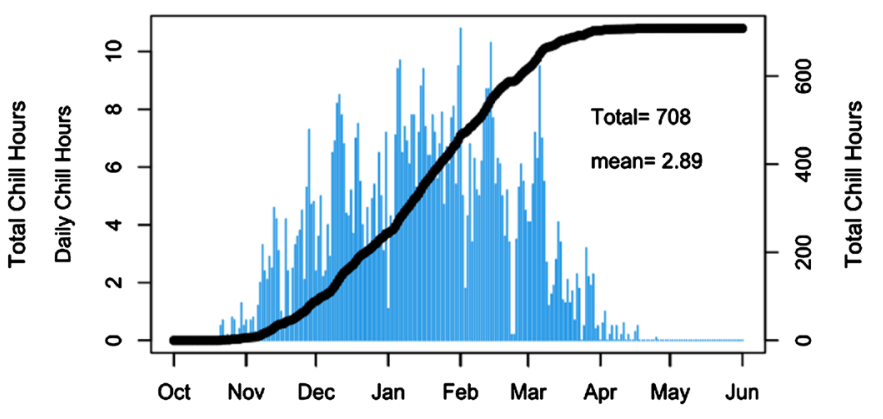

Charleston County, SC

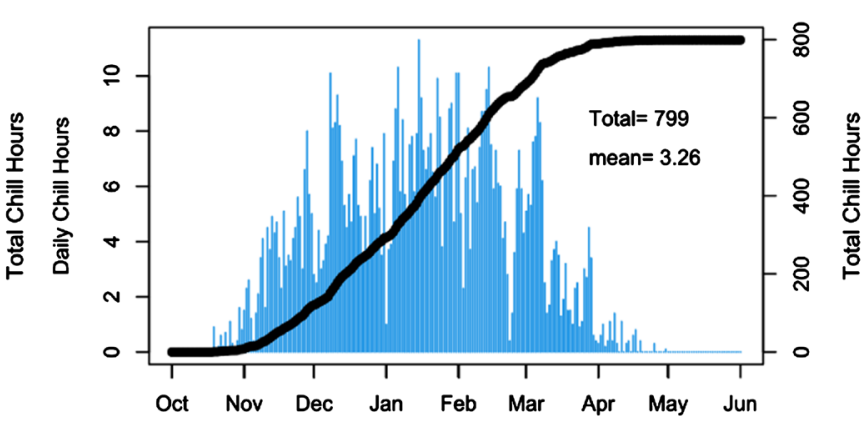

Figure 1. Daily and total chill hours of Aiken, Anderson, Barnwell, Beaufort, Berkeley, and Charleston counties, South Carolina between October to June from 2010 to 2020 . 
Chester County, SC

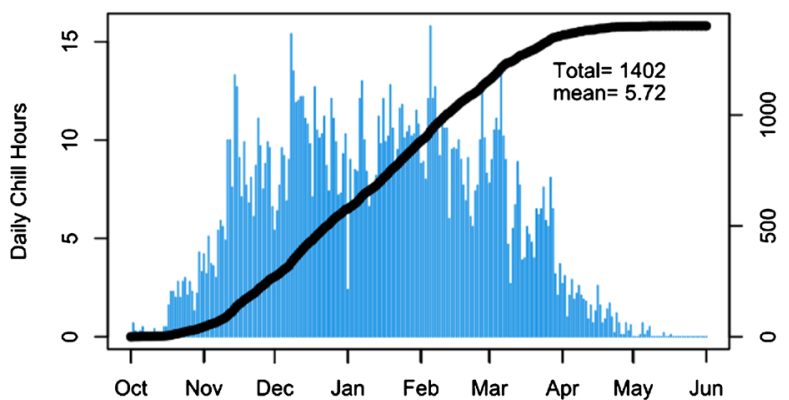

Clarendon County, SC

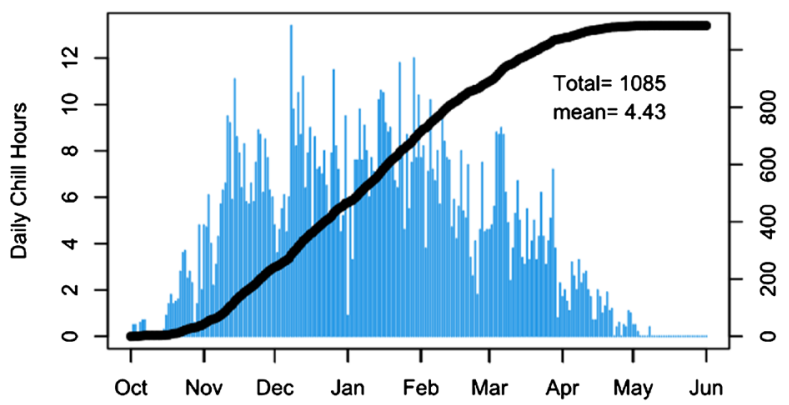

Darlington County, SC

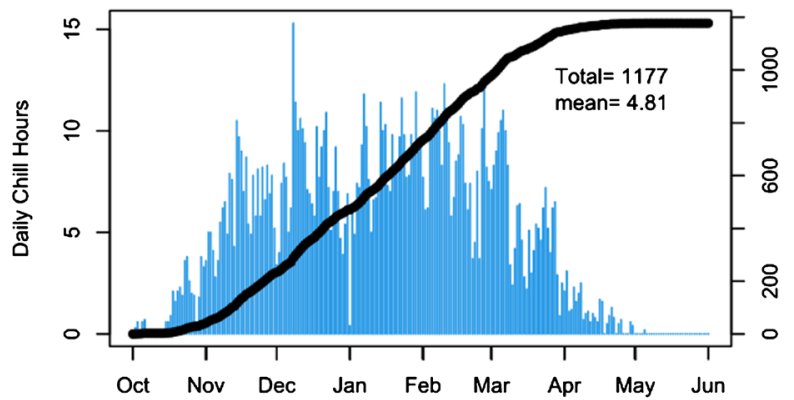

Chesterfield County, SC

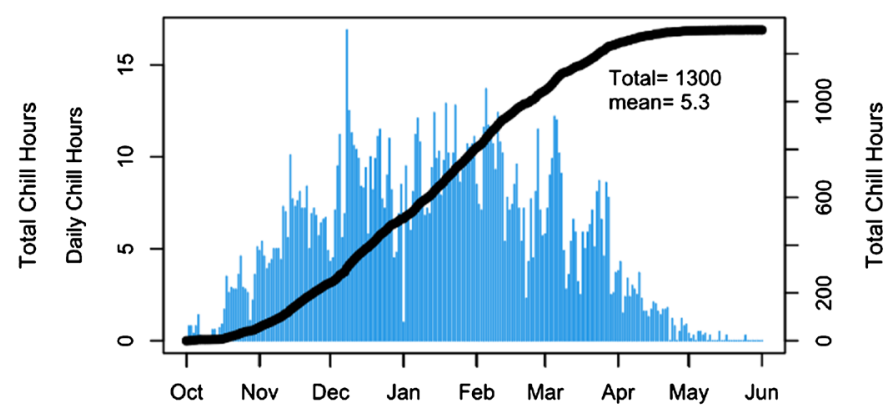

Colleton County, SC

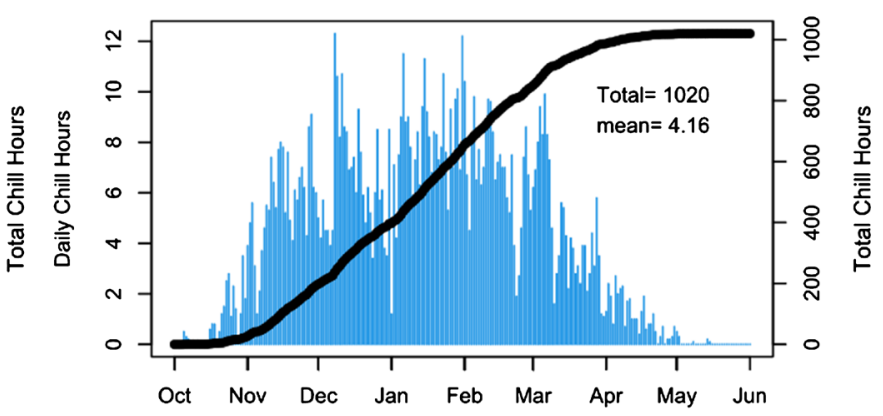

Dorchester County, SC

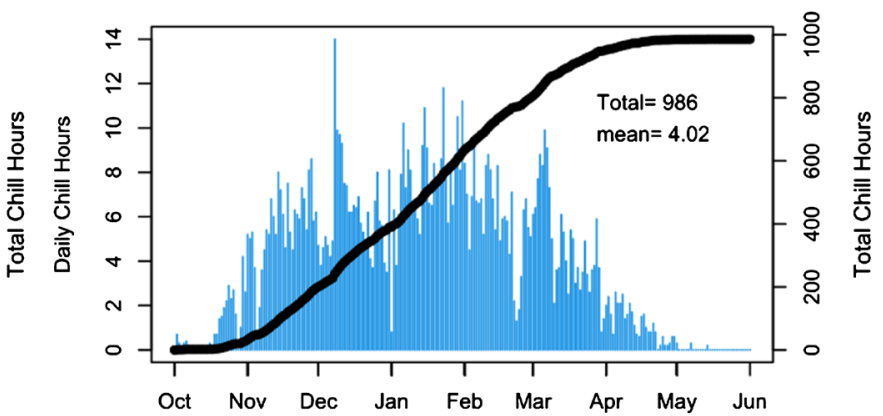

Figure 2. Daily and total chill hours of Chester, Chesterfield, Clarendon, Colleton, Darlington, and Dorchester counties, South Carolina between October to June from 2010 to 2020.

Florence County, SC

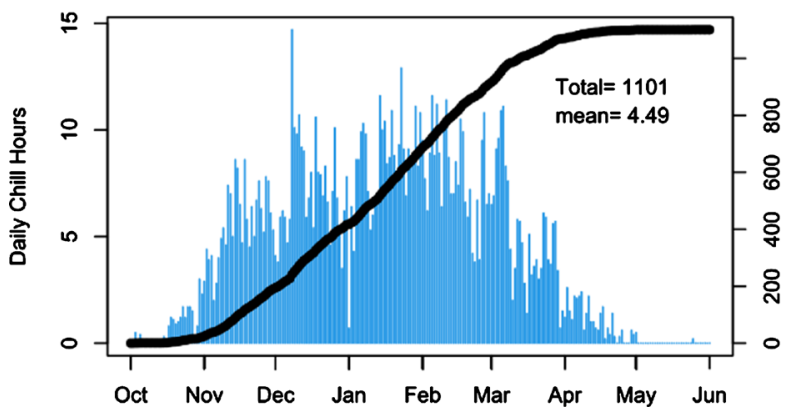

Georgetown County, SC

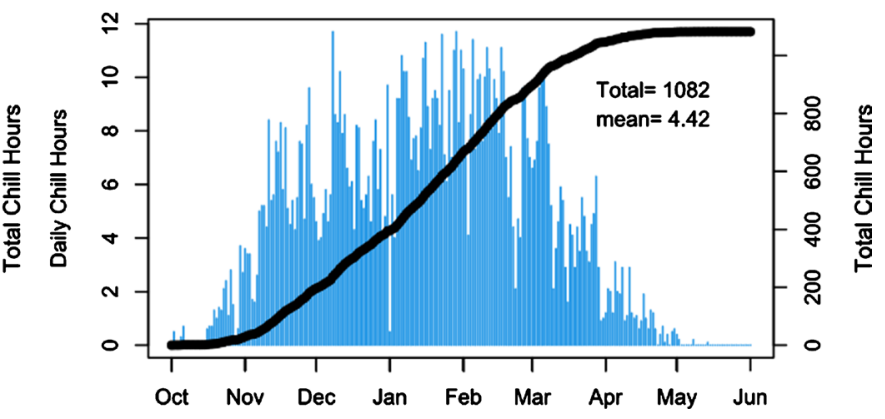


Greenville County, SC

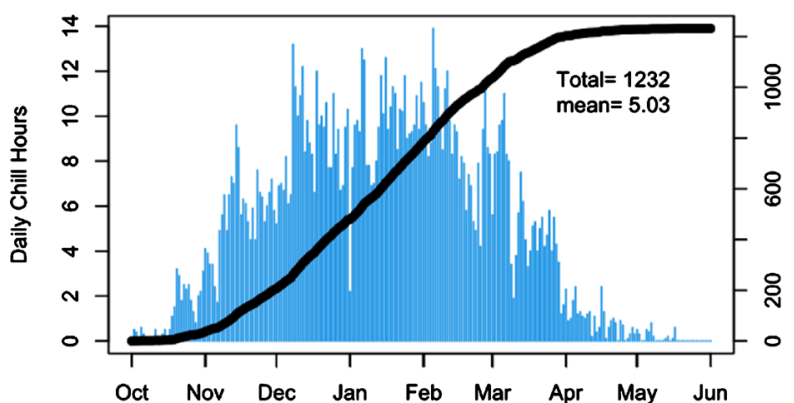

Horry County, SC

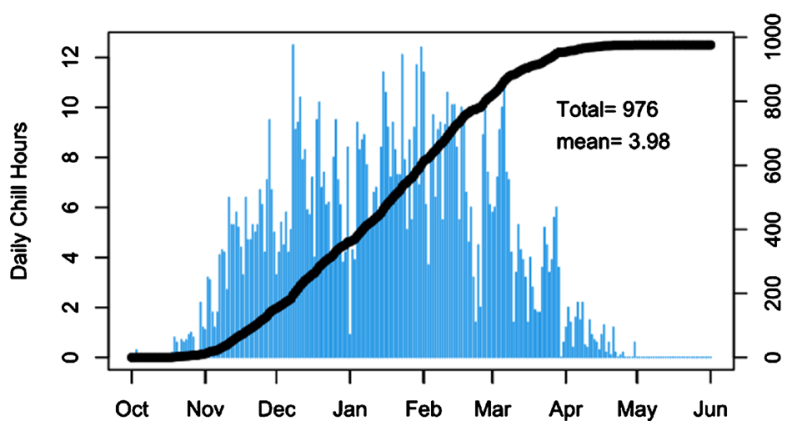

Greenwood County, SC

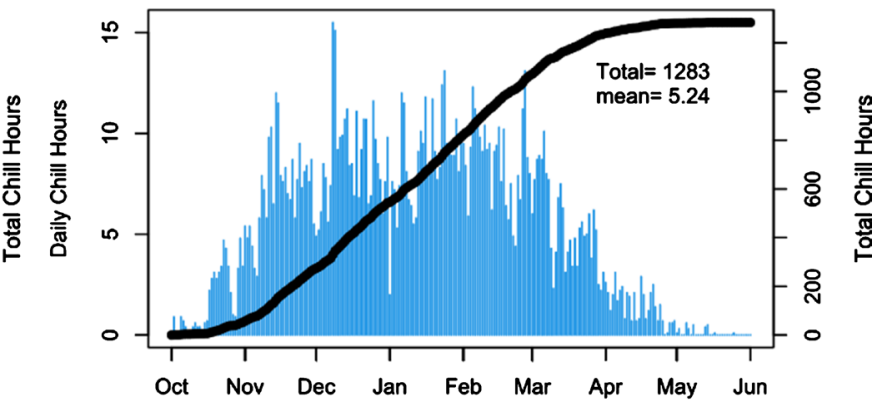

Kershaw County, SC

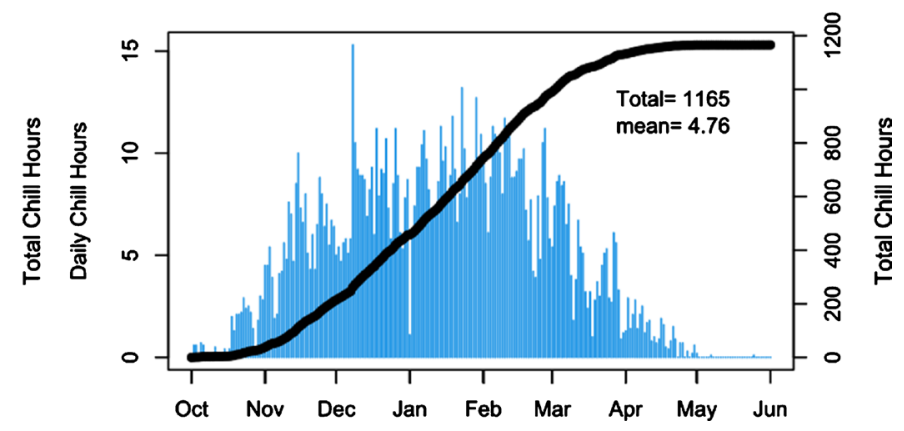

Figure 3. Daily and total chill hours of Florence, Georgetown, Greenville, Greenwood, Horry, and Kershaw counties, South Carolina between October to June from 2010 to 2020.

Lancaster County, SC

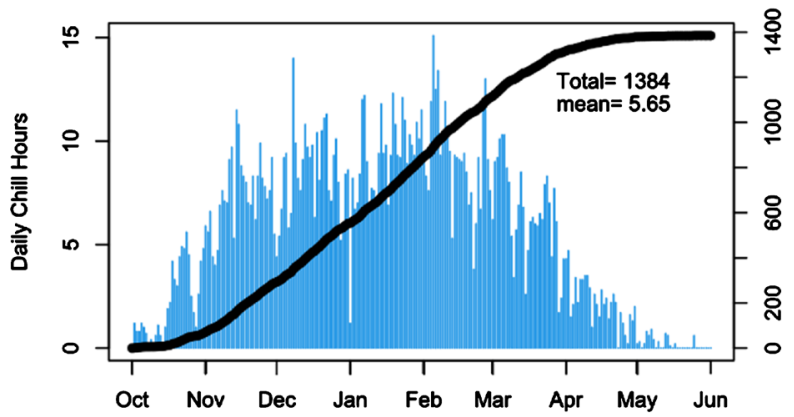

Lexington County, SC

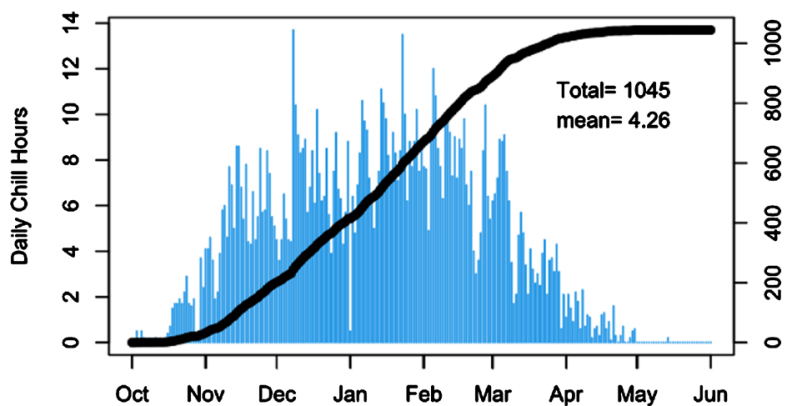

Laurens County, SC

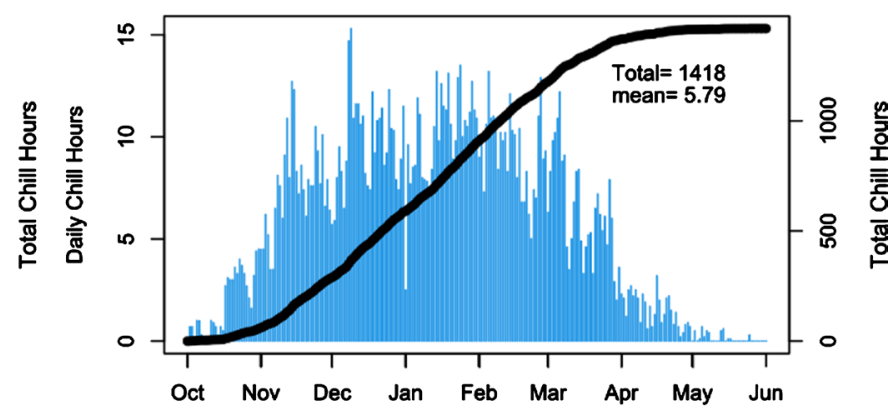

Marion County, SC

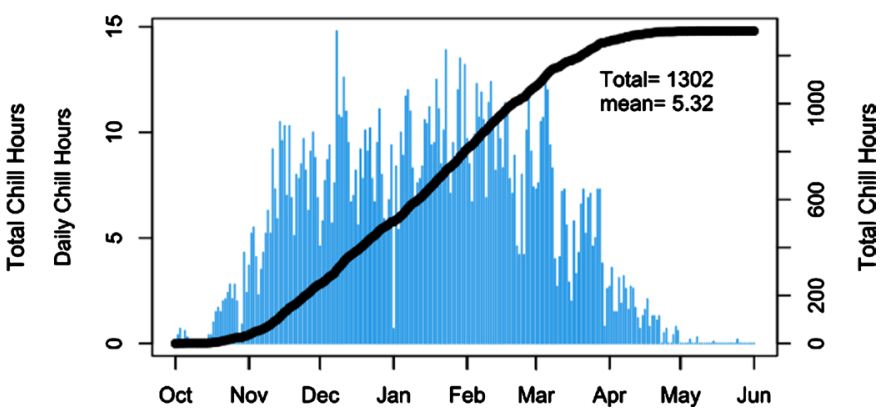



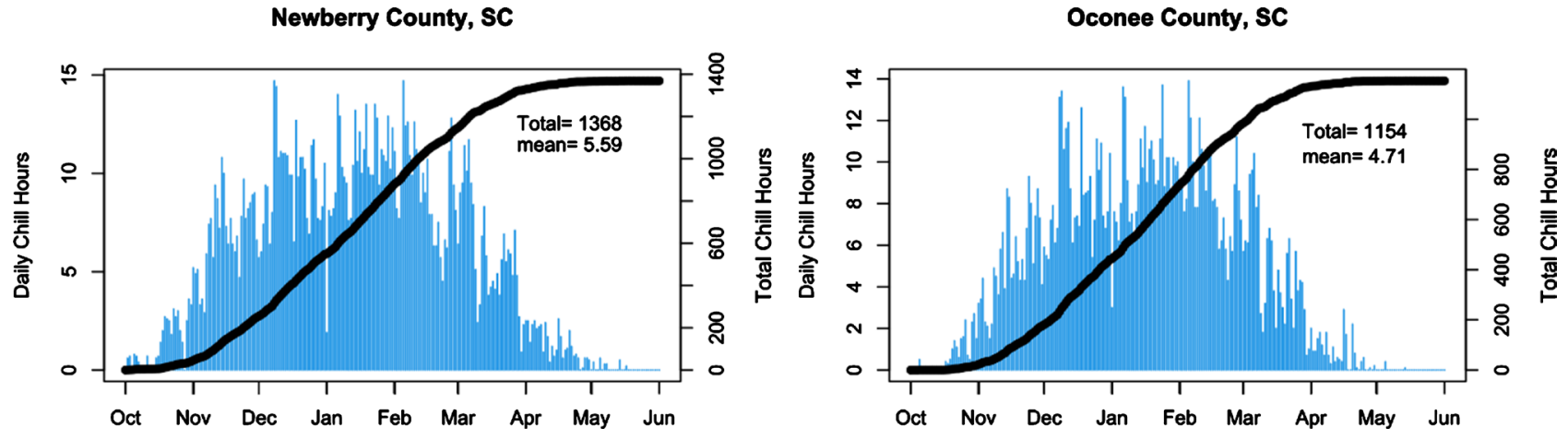

Figure 4. Daily and total chill hours of Lancaster, Laurens, Lexington, Marion, Newberry, and Oconee counties, South Carolina between October to June from 2010 to 2020.

Orangeburg County, SC

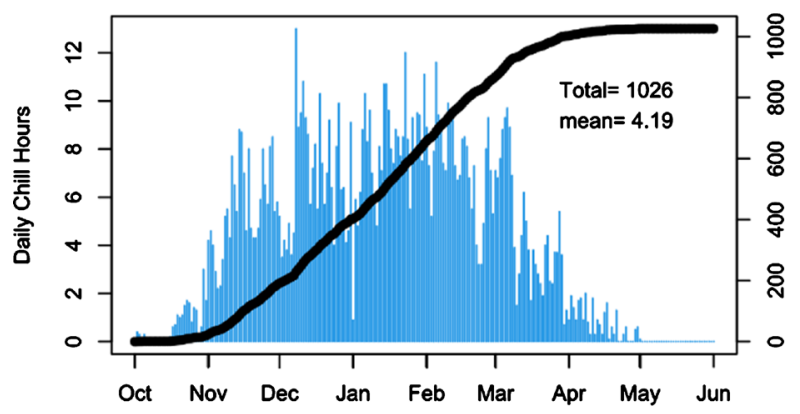

Richland County, SC

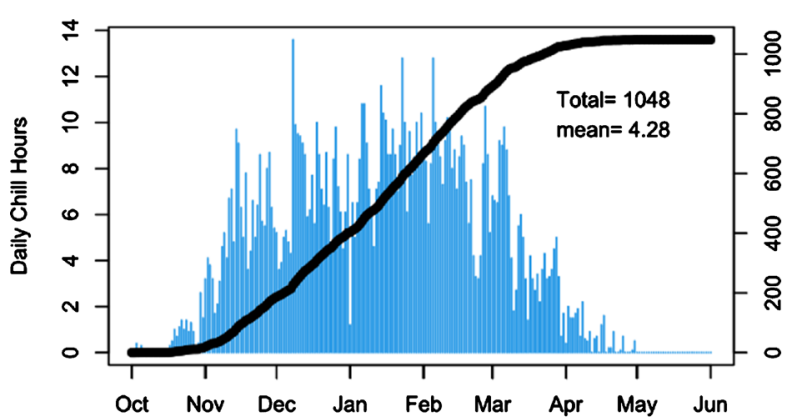

Sumter County, SC

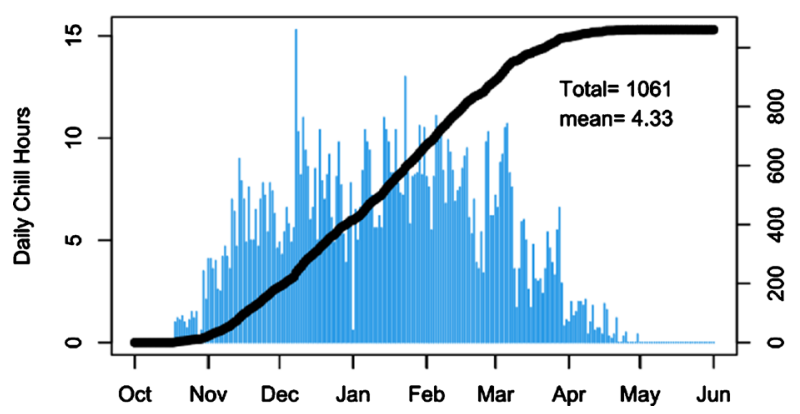

Pickens County, SC

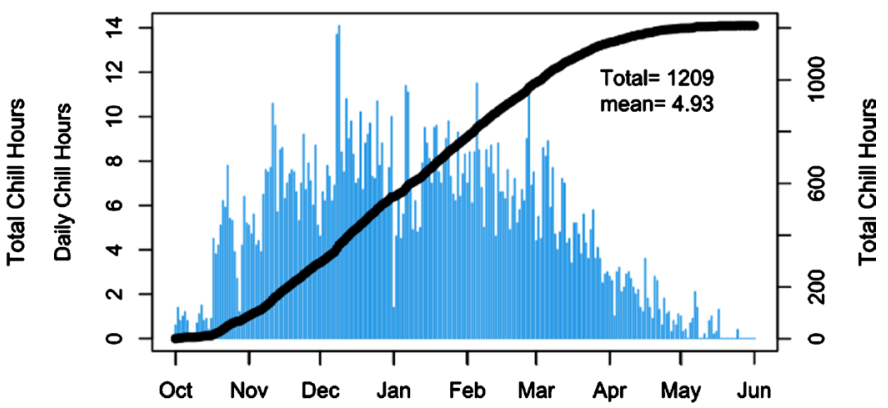

Spartanburg County, SC

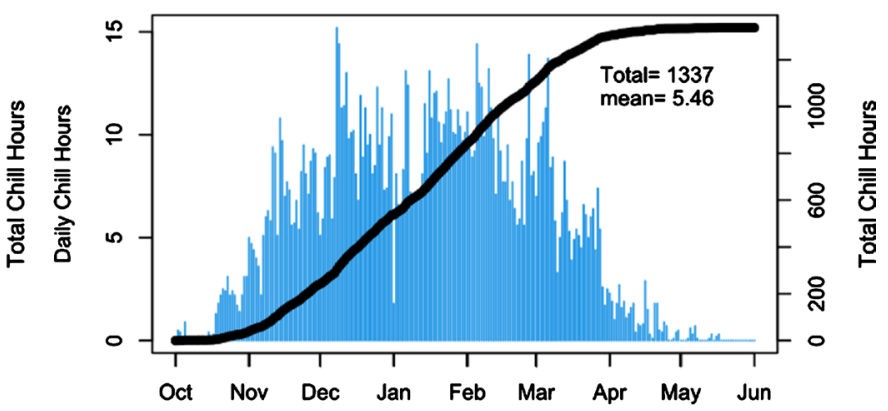

Williamsburg County, SC

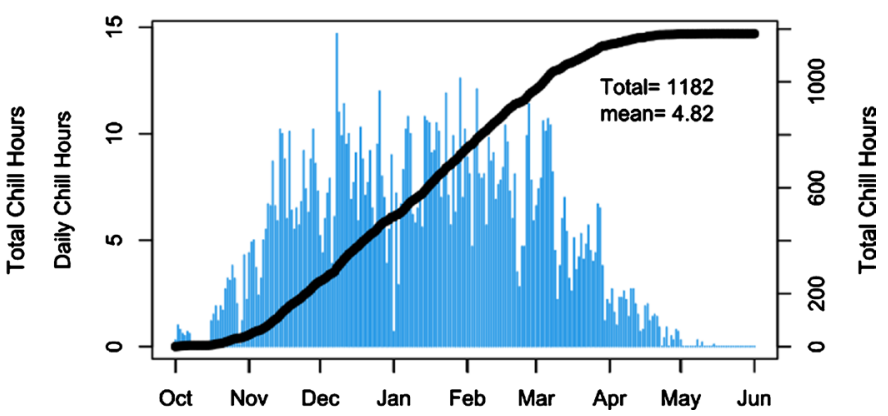




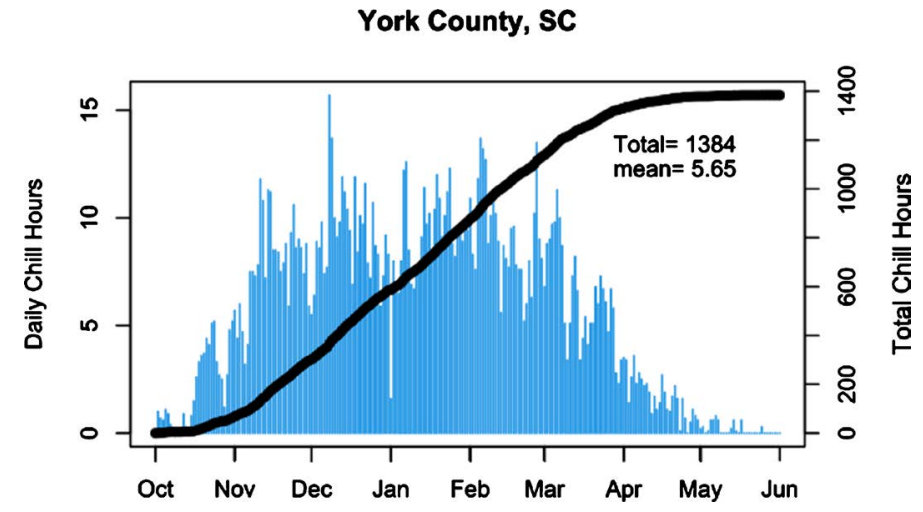

Figure 5. Daily and total chill hours of Orangeburg, Pickens, Richland, Spartanburg, Sumter, Williamsburg, and York counties, South Carolina between October to June from 2010 to 2020.

\section{South Carolina Chill Hours by County}

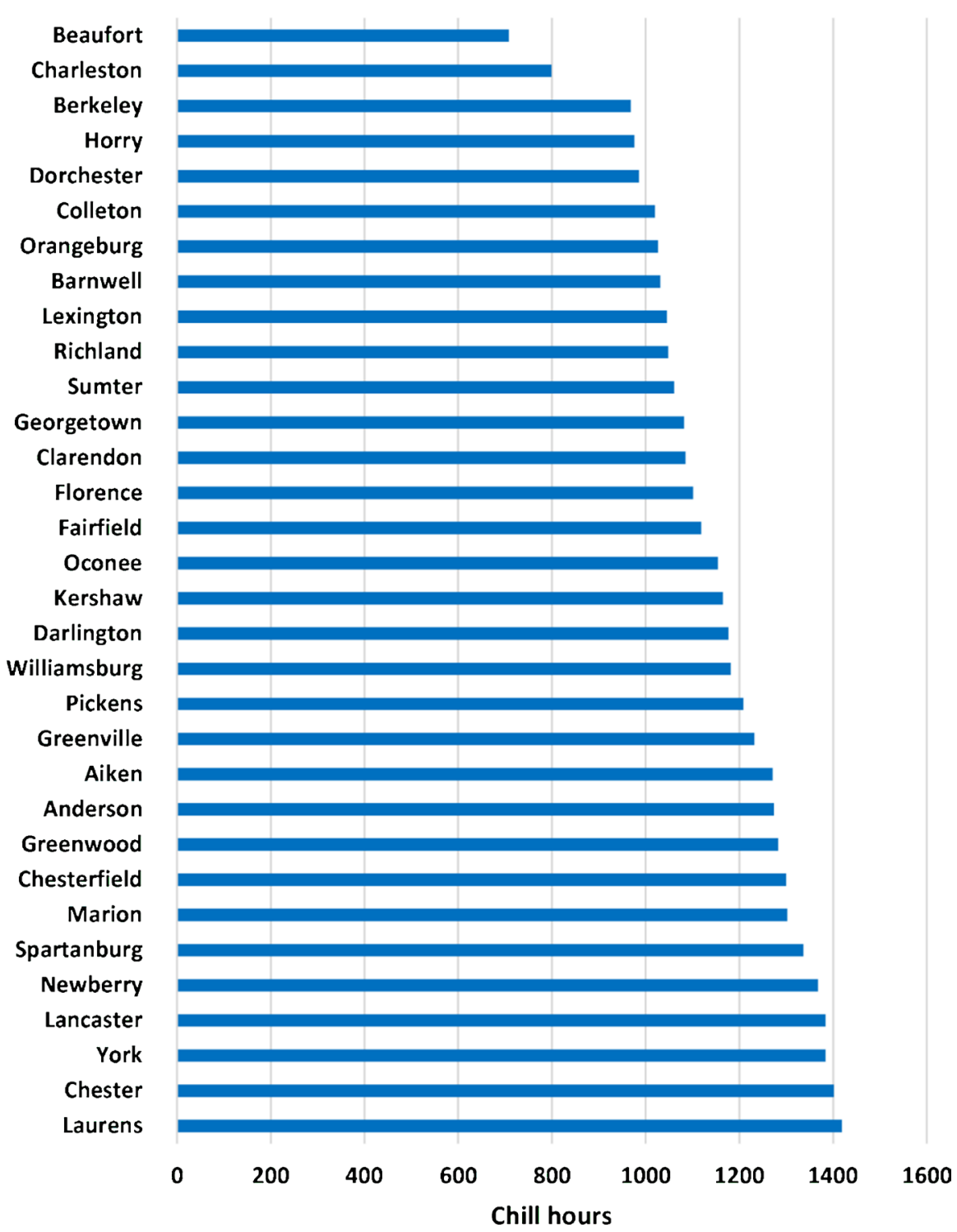

Figure 6. Long-term average of total chill hours by county in South Carolina. Some counties had no data and were not included. 
county (Figure 1), whereas, the highest mean daily chill hours were observed in Laurens county (Figure 4). Among different counties in South Carolina, Laurens County had the most prolonged total chill hours (1419 hrs) from October to June (Figure 6). The counties near the coastal regions had fewer chill hours than the counties in the inland areas. For example, Beaufort, Charleston, Berkeley, Horry, and Dorchester counties that are located near the coastal region had fewer total chill hours of 708, 799, 968, 976, and 986 hours, respectively (Figure 6). In contrast, counties located in the inland areas like Laurens, Chester, Lancaster, and York recorded the most prolonged chill hours of 1419, 1402, 1384, and 1384 hours, respectively. These observed chill hours accumulations are above the range of minimum chilling requirement of various fruit species and cultivars [7]. Our results showed both the highest and lowest chill hours accumulations across relatively short geographical ranges (Figure 7).

In winter, the coastal areas will generally have a more moderate temperature than the inland areas due to the ocean's heat capacity. Because water has a higher heat capacity than the ground, so the ocean takes a much longer time to cool and heat than the land surface. Due to this phenomenon, along the coastal areas, summer and winter temperatures are more moderate (not as hot and cold) than

\section{South Carolina Total Chill Hours by County}

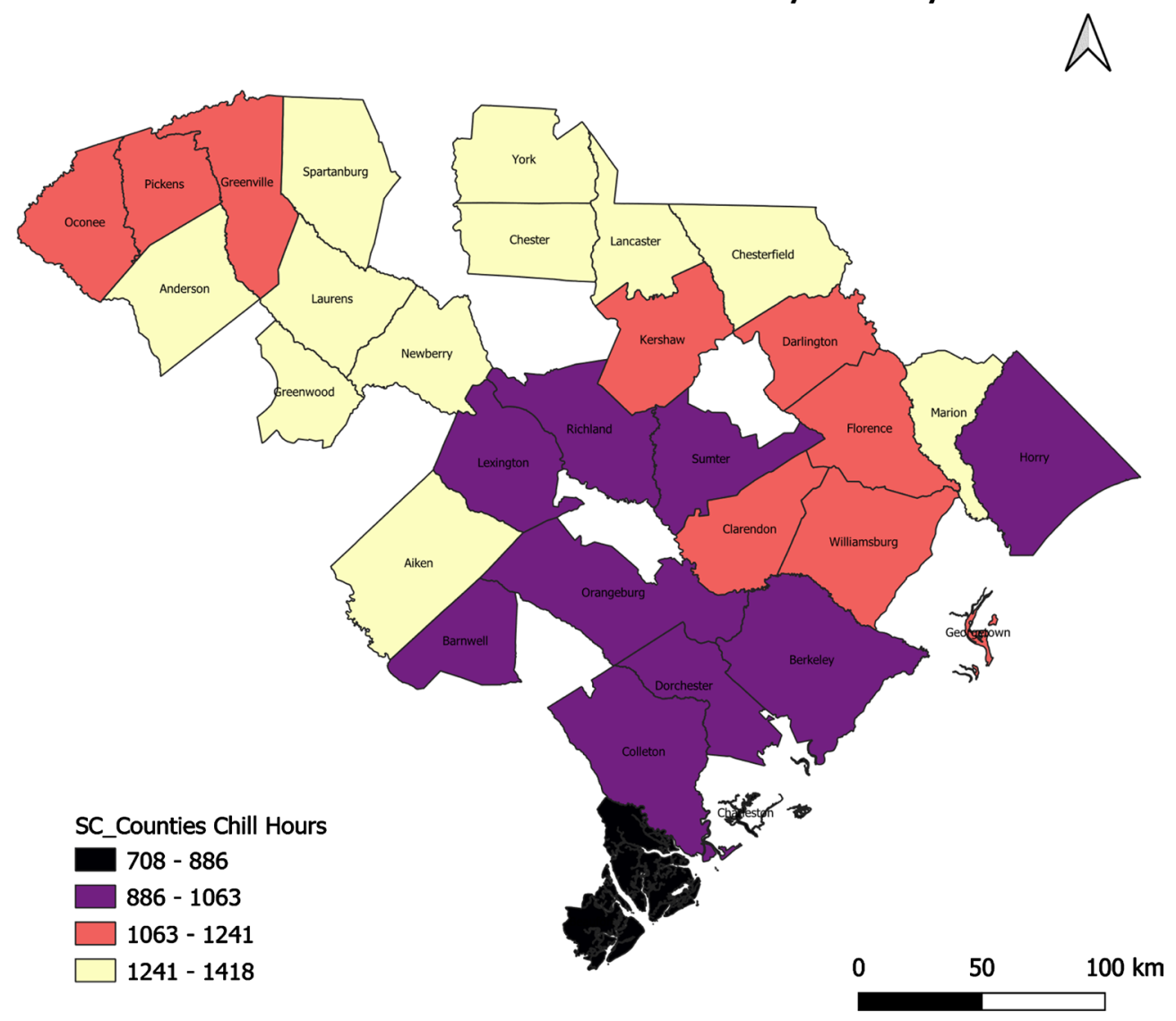

Figure 7. Map of total chill hours by county in South Carolina. Some counties had no data and were not shown. 
inland regions [26]. In summer, the soil acts as a heat sink and source, but the capacity to hold heat energy is much lower than that of water and acts as a heat source after sunset, releasing some of the energy stored during the day. Whereas, water in the ocean stores all the extra energy in the summer and becomes a heat source in winter by releasing the stored energy [26] [27]. This could be a major reason that coastal areas had increased air temperature, especially during winter, and consequently, relatively lowest chill hours compared to inland areas.

In subtropical areas, the air temperature influences the flowering and many other aspects of plant growth. Chilling requirements vary among crops, with some crops requiring many more chill hours compared with others [28]. Insufficient chill hours can affect spring growth and may result in lack of synchronization between male and female flowering, impacting the pollination and foliation processes and reducing fruit yield and quality. Therefore, it is important to properly match crops based on their chilling requirements with their suitable location. For example, crops like citrus, loquat, and guava require very little or no chilling for their growth, whereas, these crops can be injured by prolonged cold weather during winter and spring months [7]. However, crops like cherry, current, hazelnut, gooseberry, and peach require 100 to 1600 chill hours. Our findings suggest that farmers can select crops and varieties with high chilling requirement for the coastal area. Selecting crops and varieties to match the county chill hours accumulation is critical to obtain optimum crop development and production.

\section{Summary}

We have calculated the chill hour's accumulation for each county in South Carolina based on the historical hourly air temperature data for the last ten years (2010-2020). The daily chill hours were calculated by counting the number of hours when the air temperature was within $32^{\circ} \mathrm{F}$ to $45^{\circ} \mathrm{F}\left(0\right.$ to $\left.7.2^{\circ} \mathrm{C}\right)$. The total chill hours for each county were then determined by accumulating the daily chill hours starting on October $1^{\text {st }}$ to June $1^{\text {st }}$. Among different counties in South Carolina, Laurens County had the most prolonged chill hours of 1419 hrs. The chill hours were higher between November to March, and counties near the coastal regions had fewer chill hours than the counties in the inland areas. For example, Beaufort, Charleston, Berkeley, Horry, and Dorchester counties that are located near the coastal region had fewer chill hours. In contrast, counties located in the inland areas like Laurens, Chester, Lancaster, and York recorded the most prolonged chill hours. Our results suggest selecting crops and varieties with high chilling requirements for the inland areas, and crops with low chilling requirements for the coastal areas. There are no specialized weather stations that collect chill hours in South Carolina. So, South Carolina farmers can use this information as a guide for selecting crops based on their location and chilling requirements. 


\section{Acknowledgements}

Technical Contribution No. 6981 of the Clemson University Experiment Station. This material is based upon work supported by USDA-NIFA, under project number SC-1700593. Additional funding was provided by USDA-NRCS Project numbers 69-3A75-17-274 and NR203A750013G010.

\section{Conflicts of Interest}

The authors declare no conflicts of interest regarding the publication of this paper.

\section{References}

[1] Erez, A. (2000) Bud Dormancy; Phenomenon, Problems and Solutions in the Tropics and Subtropics. In: Erez, A., Ed., Temperate Fruit Crops in Warm Climates, Springer, Dordrecht, 17-48. https://doi.org/10.1007/978-94-017-3215-4 2

[2] Luedeling, E. and Brown, P.H. (2011) A Global Analysis of the Comparability of Winter Chill Models for Fruit and Nut Trees. International Journal of Biometeorology, 55, 411-421. https://doi.org/10.1007/s00484-010-0352-y

[3] Tariq, M., Yasmeen, A., Ahmad, S., Hussain, N., Afzal, M.N. and Hasanuzzaman, M. (2017) Shedding of Fruiting Structures in Cotton: Factors, Compensation and Prevention. Tropical and Subtropical Agroecosystems, 20, 251-262.

[4] Jones, H., Hillis, R., Gordon, S. and Brennan, R. (2013) An Approach to the Determination of Winter Chill Requirements for Different Ribes Cultivars. Plant Biology, 15, 18-27. https://doi.org/10.1111/j.1438-8677.2012.00590.x

[5] Campoy, J.A., Ruiz, D. and Egea, J. (2011) Dormancy in Temperate Fruit Trees in a Global Warming Context: A Review. Scientia Horticulturae, 130, 357-372.

https://doi.org/10.1016/j.scienta.2011.07.011

[6] Erez, A. and Fishman, S. (1997) The Dynamic Model for Chilling Evaluation in Peach Buds. In: Monet, R., Ed., IV International Peach Symposium, Vol. 2, International Society for Horticultural Science, Bordeaux, 465.

https://doi.org/10.17660/ActaHortic.1998.465.63

[7] Noorazar, H., Kalcsits, L., Jones, V., Jones, M. and Rajagopalan, K. (2020) The Risk for Insufficient Chill Accumulation: A Climate Change Perspective for Apple and Cherry Production in the United States. BioRxiv. (Preprint) https://doi.org/10.1101/2020.08.26.268979

[8] Sunley, R., Atkinson, C. and Jones, H. (2006) Chill Unit Models and Recent Changes in the Occurrence of Winter Chill and Spring Frost in the United Kingdom. The Journal of Horticultural Science and Biotechnology, 81, 949-958. https://doi.org/10.1080/14620316.2006.11512181

[9] Cesaraccio, C.,Spano, D., Snyder, R.L. and Duce, P. (2004) Chilling and Forcing Model to Predict Bud-Burst of Crop and Forest Species. Agricultural and Forest Meteorology, 126, 1-13. https://doi.org/10.1016/j.agrformet.2004.03.002

[10] Weinberger, J.H. (1950) Chilling Requirements of Peach Varieties. Proceedings of American Society for Horticultural Science, 56, 122-128.

[11] Milech, C.G.-C., Scariotto, S., Dini, M., Herter, F.G. and Raseira, M. (2018) Models to Estimate Chilling Accumulation under Subtropical Climatic Conditions in Brazil. Embrapa Clima Temperado-Artigo em periódico indexado (ALICE), 23, 106-115. https://doi.org/10.5380/abclima.v23i0.53086 
[12] Fishman, S., Erez, A. and Couvillon, G. (1987) The Temperature Dependence of Dormancy Breaking in Plants: Mathematical Analysis of a Two-Step Model Involving a Cooperative Transition. Journal of Theoretical Biology, 124, 473-483. https://doi.org/10.1016/S0022-5193(87)80221-7

[13] Linsley-Noakes, G. and Allan, P. (1994) Comparison of Two Models for the Prediction of Rest Completion in Peaches. Scientia Horticulturae, 59, 107-113. https://doi.org/10.1016/0304-4238(94)90077-9

[14] Byrne, D.H. and Bacon, T. (1992) Chilling Estimation: Its Importance and Estimation. The Texas Horticulturist, 18, 8-9.

[15] Gilreath, P., Phyllis, R. and Buchanan, D.W. (1981) Rest Prediction Model for LowChilling "Sungold" Nectarine. Journal of the American Society for Horticultural Science, 106, 426-429.

[16] Chavarria, G., Raseira, M.d.C. and Zanandrea, A. (2000) Chilling Requirement in Peach. In: do Carmo Bassols Raseira, M. and Nakasu, B., Eds., Fruit Breeders Meeting, Embrapa Clima Temperado, Pelotas, 78-80.

[17] Ou, S. and Chen, C. (2000) Estimation of the Chilling Requirement and Development of a Low-Chill Model for Local Peach Trees in Taiwan. Journal of the Chinese Society for Horticultural Science, 46, 337-350.

[18] Lamb, R.C. (1948) Effect of Temperatures above and below Freezing on the Breaking of Rest in the Latham Raspberry. Proceedings of the American Society for Horticultural Science, 51, 313-315.

[19] Eggert, F.P. (1951) A Study of Rest in Several Varieties of Apple and in Other Fruit Species Grown in New York State. Proceedings of the American Society for Horticultural Science, 51, 161-177.

[20] Erez, A. (1971) The Effect of Climatic Condition on Dormancy Development of Peach Buds. I. Temperature. Journal of the American Society for Horticultural Science, 96, 711-714.

[21] Richardson, E.A., Seeley, S. and Walker, D. (1974) A Model for Estimating the Completion of Rest for "Redhaven" and "Elberta" Peach Trees. HortScience, 9, 331-332.

[22] Linvill, D.E. (1990) Calculating Chilling Hours and Chill Units from Daily Maximum and Minimum Temperature Observations. HortScience, 25, 14-16.

https://doi.org/10.21273/HORTSCI.25.1.14

[23] Luedeling, E., Gebauer, J. and Buerkert, A. (2009) Climate Change Effects on Winter Chill for Tree Crops with Chilling Requirements on the Arabian Peninsula. Climatic Change, 96, 219-237. https://doi.org/10.1007/s10584-009-9581-7

[24] National Weather Service (NWS) (2020) JetStream MAX: Addition Köppen Climate Subdivisions. http://www.weather.gov

[25] Team, R.C. (2020) R: A Language and Environment for Statistical Computing. R Foundation for Statistical Computing, Vienna. https://www.r-project.org/

[26] Fortner, R.W. and Mayer, V.J. (2009) How Is Coastal Temperature. Science Activities, 46, 20-26. https://doi.org/10.3200/SATS.46.3.20-26

[27] Miller, H. and Sheaffer, A.L. (1996) Great Lakes Climate and Water Movement. Earth Systems-Education Activities for Great Lakes Schools (ES-EAGLS). Report No. EP083, Ohio State University, Columbus.

[28] Warmund, M.R. and Krumme, J. (2005) A Chilling Model to Estimate Rest Completion of Erect Blackberries. HortScience, 40, 1259-1262.

https://doi.org/10.21273/HORTSCI.40.5.1259 